\title{
Immunohistochemical Studies on Small Intestinal Mucosa in Kawasaki Disease
}

\author{
SATORU NAGATA, YUICHIRO YAMASHIRO, MASATO MAEDA, YOSHIKAZU OHTSUKA, AND \\ KEIJIRO YABUTA \\ Department of Paediatrics, Juntendo University School of Medicine, Tokyo, Japan
}

\begin{abstract}
To investigate the etiology of Kawasaki disease (KD), the cell surface phenotypes of mononuclear cells and enterocytes in the jejunal mucosa of KD were investigated in a case-control study. Sixteen Japanese patients with KD were enrolled in the study. As disease controls, jejunal tissues from 10 patients with diarrhea due to cow's milk protein intolerance were used. The numbers of cells stained by an immunofluorescent technique were counted and analyzed statistically by $t$ test. Both HLA$\mathrm{DR}^{+} \mathrm{CD3}^{+}$and $\mathrm{DR}^{+} \mathrm{CD4}^{+}$cells were significantly increased in the lamina propria of KD patients in the acute phase compared with numbers in controls and patients with cow's milk protein intolerance $(p \leq 0.01)$. $\mathrm{CD8}^{+}$cells were significantly reduced in both the epithelium and the lamina propria of KD patients in the acute phase in comparison with numbers in both controls $(p \leq 0.05)$ and patients with cow's milk protein intolerance $(p \leq 0.01)$. HLA-DR ${ }^{+}$cells were significantly increased in both the enterocytes and the lamina propria of KD patients in the acute phase compared with numbers in controls $(p \leq 0.01)$. These cell patterns returned to normal in the convalescent phase of KD. Differences between these cell patterns in KD patients with and without diarrhea were not significant, although these immunohistochemical features tended to be more marked in patients with diarrhea than in those who lacked diarrhea. These results are consistent with what one would expect to find if a delayed-type hypersensitivity reaction had occurred in the small intestinal mucosa of KD patients. Although other explanations cannot be ruled out, it is conceivable that causative antigens may have invaded the body by breaching the barrier of the intestinal mucosa. (Pediatr Res 33: 557-563, 1993)
\end{abstract}

\section{Abbreviations}

KD, Kawasaki disease

IEL, intraepithelial lymphocyte

CMPI, cow's milk protein intolerance

GI, gastrointestinal

The etiology of KD remains unknown. This disease is an acute systemic vasculitis of early childhood, characterized by fever, rash, mucosal inflammation, and coronary artery damage in 15 to $20 \%$ of patients $(1,2)$.

The acute phase of the illness is marked by profound immunoregulatory changes that include a reduction in $\mathrm{CD} 8^{+}$cells, an increase in activated $\left(\mathrm{DR}^{+}\right)$circulating $\mathrm{CD} 4^{+}$cells, and marked

Received May 8, 1992; accepted February 2, 1993.

Correspondence and reprint requests: Satoru Nagata, M.D., Department of Paediatrics, Juntendo University School of Medicine, 2-1-1, Hongo, Bunkyo-ku, Tokyo, 113. polyclonal $\mathrm{B}$ cell activation in peripheral blood mononuclear cells $(3,4)$. In addition to investigations of peripheral blood, immunohistochemical studies of coronary endothelial cells and skin lesions have also been reported $(5,6)$.

As GI tract involvement, e.g. diarrhea and/or protein-losing enteropathy, is often the initial symptom seen in $K D$, we were prompted to carry out an immunohistochemical investigation of the mucosa of the small intestine. This was done in a case-control study.

\section{MATERIALS AND METHODS}

Subjects. Our subjects were nine Japanese KD patients who had diarrhea (six males and three females, aged 11 mo to $3 \mathrm{y}$; mean age $1.6 \mathrm{y}$ ) and seven who did not have diarrhea (four males and three females, aged 10 mo to $3.1 \mathrm{y}$; mean age $1.5 \mathrm{y}$ ); their diagnoses were made in accordance with the clinical criteria for KD (Table 1).

Jejunal biopsy specimens, taken in the acute and convalescent phases, were examined by immunofluorescence methods. Histologically normal intestinal tissues from 11 children who did not have diarrhea (six males and five females, aged 8 mo to $3 \mathrm{y}$; mean age $1.5 \mathrm{y}$ ), obtained from surgical cases, were used as controls (Table 2). As disease controls, we used jejunal mucosa from 10 untreated patients who had diarrhea due to CMPI (five males and five females, aged 6 mo to $2.3 \mathrm{y}$; mean age $1.3 \mathrm{y}$ ). Their diagnoses were based on clinical history, a positive provo-

Table 1. KD patients

\begin{tabular}{|c|c|c|c|c|}
\hline No. & Age & Sex & $\begin{array}{l}\text { Days } \\
\text { after } \\
\text { onset* }\end{array}$ & GI tract symptoms \\
\hline \multicolumn{5}{|c|}{ With diarrhea } \\
\hline 1 & 1 y $3 \mathrm{mo}$ & $\mathrm{M}$ & 10 & Diarrhea \\
\hline 2 & $11 \mathrm{mo}$ & $\mathrm{M}$ & 9 & $\begin{array}{l}\text { Diarrhea (severe), protein- } \\
\text { losing }\end{array}$ \\
\hline 3 & 2 y $1 \mathrm{mo}$ & $\mathrm{M}$ & 7 & Diarrhea \\
\hline 4 & 1 y $3 \mathrm{mo}$ & M & 7 & Diarrhea, vomiting \\
\hline 5 & 1 y $4 \mathrm{mo}$ & M & 8 & Diarrhea \\
\hline 6 & 2 y $3 \mathrm{mo}$ & M & 7 & Diarrhea, vomiting \\
\hline 7 & 1 y $3 \mathrm{mo}$ & $\mathrm{F}$ & 8 & Diarrhea \\
\hline 8 & $1 \mathrm{y} 1 \mathrm{mo}$ & $\mathrm{F}$ & 6 & Diarrhea \\
\hline 9 & 3 y 0 mo & $\mathrm{F}$ & 9 & Diarrhea \\
\hline \multicolumn{5}{|c|}{ Without diarrhea } \\
\hline 1 & 1 y $6 \mathrm{mo}$ & $\mathrm{M}$ & 7 & \\
\hline 2 & 2 y $8 \mathrm{mo}$ & M & 8 & \\
\hline 3 & 1 y $5 \mathrm{mo}$ & M & 7 & \\
\hline 4 & 3 y $1 \mathrm{mo}$ & M & 6 & \\
\hline 5 & $10 \mathrm{mo}$ & $F$ & 6 & \\
\hline 6 & $1 \mathrm{y} 1 \mathrm{mo}$ & $\mathrm{F}$ & 7 & \\
\hline 7 & 1 y 2 mo & $\mathrm{F}$ & 8 & \\
\hline
\end{tabular}

\footnotetext{
* Time that biopsy was performed.
} 
Table 2. Controls

\begin{tabular}{|c|c|c|c|}
\hline No. & Age & Sex & Original disease \\
\hline \multicolumn{4}{|c|}{ Normal controls } \\
\hline 1 & $8 \mathrm{mo}$ & $M$ & Jejunal stenosis \\
\hline 2 & $1 \mathrm{y} 0 \mathrm{mo}$ & M & Jejunal stenosis \\
\hline 3 & 1 y $6 \mathrm{mo}$ & M & Jejunal stenosis \\
\hline 4 & 1 y $3 \mathrm{mo}$ & $M$ & Jejunal stenosis \\
\hline 5 & 2 y 6 mo & $\mathrm{M}$ & $\begin{array}{l}\text { Congenital biliary atresia } \\
\text { (reoperation) }\end{array}$ \\
\hline 6 & 3 y 0 mo & $\mathrm{M}$ & $\begin{array}{l}\text { Congenital biliary atresia } \\
\text { (reoperation) }\end{array}$ \\
\hline 7 & 2 y $0 \mathrm{mo}$ & $\mathrm{F}$ & Jejunal stenosis \\
\hline 8 & $1 \mathrm{y} 1 \mathrm{mo}$ & $\mathrm{F}$ & Jejunal stenosis \\
\hline 9 & 1 y 2 mo & $\mathrm{F}$ & Jejunal stenosis \\
\hline 10 & 1 y 2 mo & $\mathrm{F}$ & $\begin{array}{l}\text { Congenital biliary atresia } \\
\text { (reoperation) }\end{array}$ \\
\hline 11 & 1 y $6 \mathrm{mo}$ & $\mathrm{F}$ & $\begin{array}{l}\text { Congenital biliary atresia } \\
\text { (reoperation) }\end{array}$ \\
\hline \multicolumn{4}{|c|}{ Disease controls (CMPI) } \\
\hline 1 & $6 \mathrm{mo}$ & M & Diarrhea, vomiting \\
\hline 2 & $9 \mathrm{mo}$ & $\mathrm{M}$ & Diarrhea, vomiting \\
\hline 3 & 1 y 2 mo & $\mathrm{M}$ & $\begin{array}{l}\text { Diarrhea (severe), vomit- } \\
\text { ing }\end{array}$ \\
\hline 4 & 1 y $4 \mathrm{mo}$ & $\mathrm{M}$ & Diarrhea \\
\hline 5 & $8 \mathrm{mo}$ & $\mathrm{F}$ & Diarrhea \\
\hline 6 & $11 \mathrm{mo}$ & $\mathrm{F}$ & Diarrhea \\
\hline 7 & 1 y $6 \mathrm{mo}$ & $\mathrm{F}$ & Diarrhea \\
\hline 8 & 1 y $9 \mathrm{mo}$ & $\mathrm{F}$ & Diarrhea \\
\hline 9 & 2 y 2 mo & $\mathrm{F}$ & Diarrhea \\
\hline 10 & 2 y 4 mo & $\mathrm{F}$ & Diarrhea \\
\hline
\end{tabular}

cation test, histologic findings, and clinical and histologic improvement on a cow's milk-free diet.

Of the nine KD patients who had diarrhea, one had severe watery diarrhea accompanied by protein-losing enteropathy that lasted for $8 \mathrm{~d}$. Coronary aneurysms appeared on the 10th $\mathrm{d}$ after onset of the disease (Table 1, KD: case 2). The other patients in this category had diarrhea but no coronary aneurysms, although they displayed mild coronary dilation.

All the families of the patients and the control subjects consented to participate in the study.

Specimens. The jejunal biopsies were obtained with a pediatric Crosby-type capsule; the control specimens were obtained by surgical incision. The first biopsy, in the acute phase of $\mathrm{KD}$, was performed about $7 \mathrm{~d}$ after the onset, when the patients' condition had stabilized.

The second biopsy, in the convalescent phase, was performed 1 mo after the fever resolved.

The freshly obtained biopsies were oriented, rapidly frozen in liquid nitrogen, and stored at $-80^{\circ} \mathrm{C}$ until processed.

Immunofluorescent studies. Four- $\mu \mathrm{m}$-thick frozen sections were cut, fixed in cold acetone, and stained with biotinylated antibodies, followed by avidin-FITC or avidin-phycoerythrin. Double staining of the tissue was carried out by staining first with biotinylated antibodies and avidin-phycoerythrin and then with FITC-labeled antibodies.

The specimens were examined under a Zeiss incident-light fluorescent microscope. The antibodies used were those against Leu2 (CD8), Leu 3 (CD4), Leu4 (CD3), and HLA-DR (Becton Dickinson, Mountain View, CA). The stained epithelial and lamina propria cells were counted using a counting grid incorporated into the eyepiece of the microscope. Counting was performed with the $\times 40$ objective in $10 \times 10$ squares of the grid. The count of lamina propria cells was expressed as the number of stained cells per $\mathrm{mm}^{2}$ of lamina propria. In the epithelial cells, we counted the number of stained cells per 300 enterocytes and expressed this as the number per 100 enterocytes. Statistical analysis was performed using the $t$ test.

\section{RESULTS}

Hematoxylin and eosin staining. Figure 1 shows the hematoxylin and eosin staining of jejunal mucosa obtained from a KD patient. There were no distinct morphologic changes such as

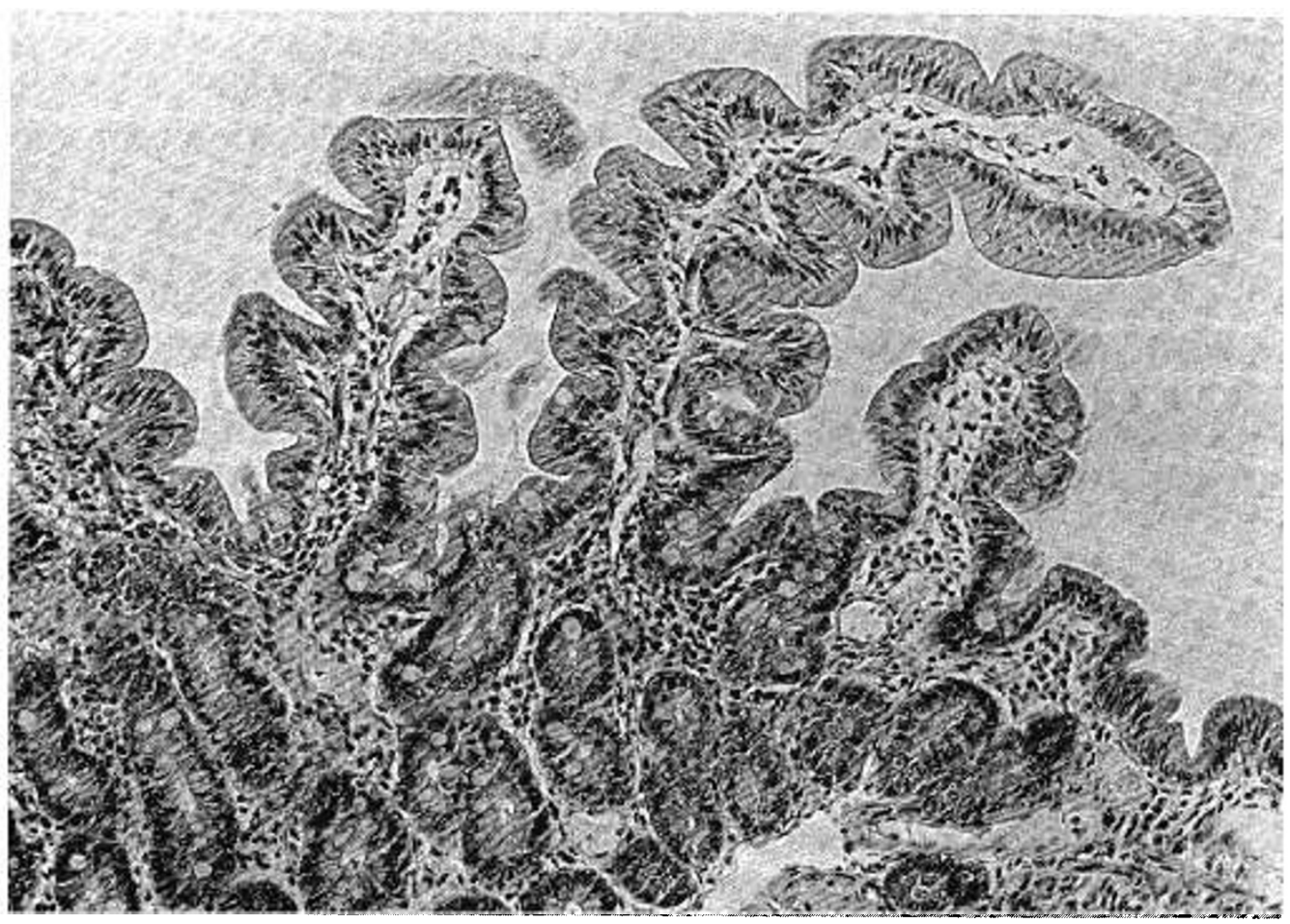

Fig. 1. Hematoxylin and eosin staining of jejunal mucosa obtained from a KD patient in the acute phase $(\times 100)$. There were no distinct morphologic changes such as villous atrophy or crypt hyperplasia, apart from a mild to moderate increase in cells infiltrating the lamina propria. 


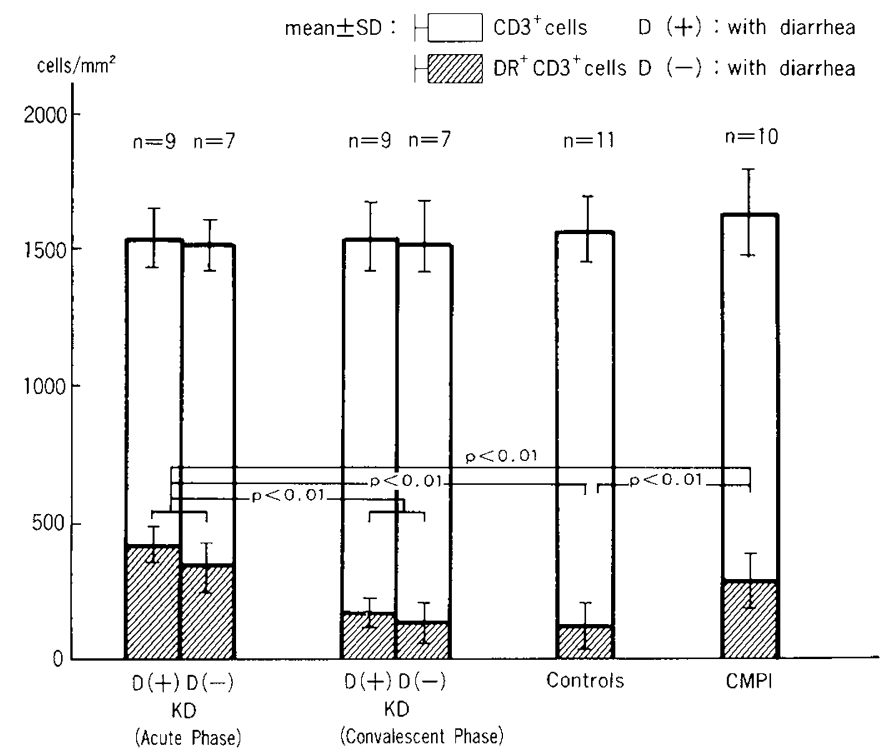

Fig. 2. Numbers of $\mathrm{CD}^{+}$and $\mathrm{DR}^{+} \mathrm{CD}^{+}$cells per $\mathrm{mm}^{2}$ of lamina propria. $\mathrm{DR}^{+} \mathrm{CD}^{+}$cells were significantly increased in the acute phase in $\mathrm{KD}$ patients compared with both controls and CMPI patients ( $p \leq$ $0.01)$.

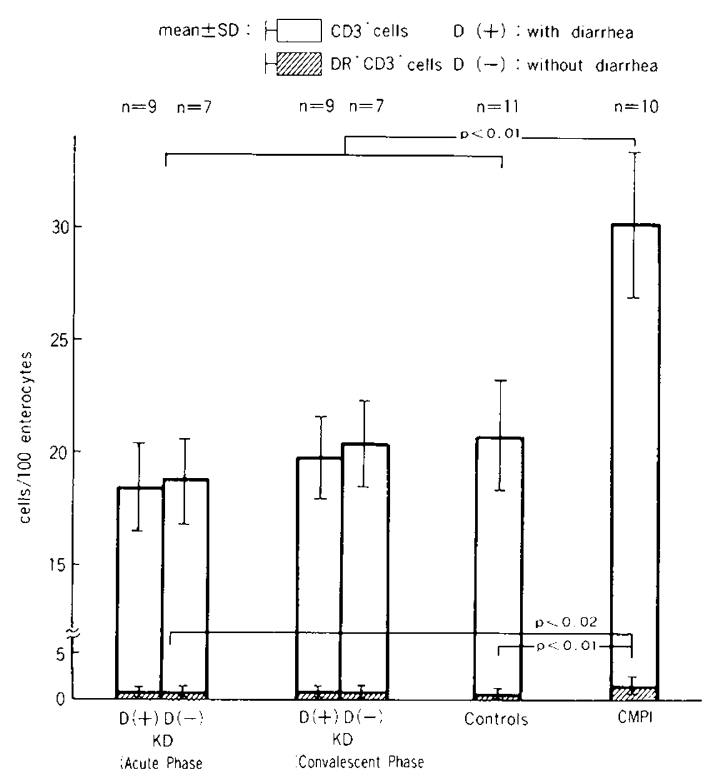

Fig. 3. Numbers of intraepithelial $\mathrm{CD}^{+}$and $\mathrm{DR}^{+} \mathrm{CD}^{+}$cells per 100 enterocytes. Intraepithelial $\mathrm{CD}^{+}$cells tended to be reduced in the acute phase of KD. In contrast, they were significantly increased in CMPI ( $p$ $\leq 0.01)$.

villous atrophy or crypt hyperplasia, apart from a mild to moderate increase in cells infiltrating the lamina propria. This occurred irrespective of whether a patient presented with diarrhea. In contrast, in CMPI, distinct mucosal atrophy and increasing numbers of IEL were observed.

Immunofluorescent staining. Comparison of the total number of $\mathrm{CD}^{+}$cells in the mucosa in the acute and convalescent phases of $\mathrm{KD}$ and in controls showed no significant difference. In the lamina propria, $\mathrm{HLA}-\mathrm{DR}^{+} \mathrm{CD} 3^{+}$cells were significantly increased in the acute phase of $\mathrm{KD}$ in comparison with both controls and tissue from CMPI patients (Fig. 2).

Intraepithelial $\mathrm{CD}^{+}$cells tended to be reduced in the acute phase of $\mathrm{KD}$, whereas they were significantly increased in CMPI. There were relatively few $\mathrm{DR}^{+} \mathrm{CD}^{+}$cells in the IEL. This difference between $\mathrm{KD}$ patients and controls was statistically significant (Fig. 3).
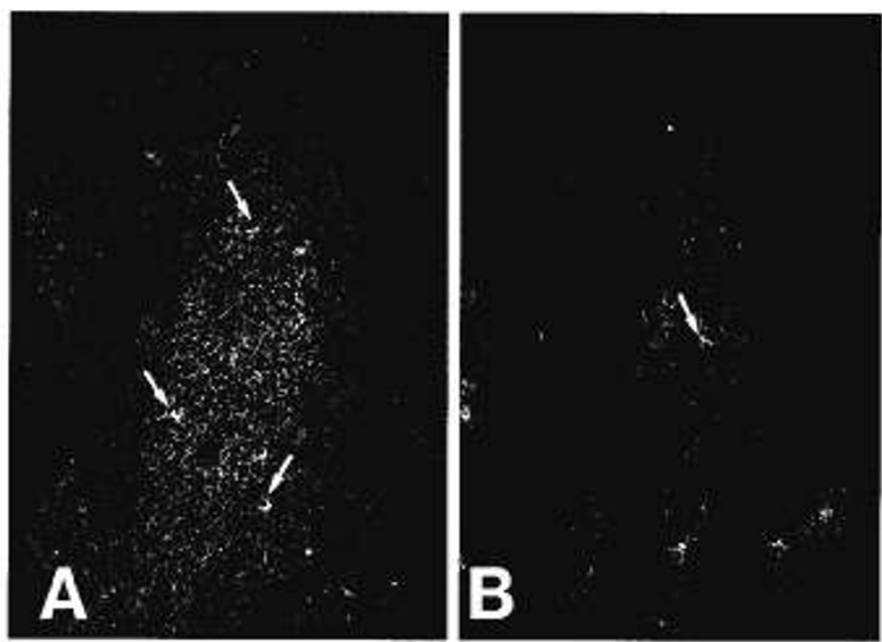

Fig. 4. $A, \mathrm{CD}^{+}$and HLA-DR ${ }^{+}$cells in the mucosa of the small intestine of $\mathrm{KD}$ in the acute phase. $B$, These cells in a control $(\times 200)$. $\mathrm{CD}^{+}$cells are stained green, $\mathrm{DR}^{+}$cells are stained red, and $\mathrm{DR}^{+} \mathrm{CD} 4^{+}$ cells are stained yellow. In both $\mathrm{KD}$ and control specimens, most of the $\mathrm{CD}^{+}$cells were found in the lamina propria. $\mathrm{DR}^{+} \mathrm{CD}^{+}$cells in the lamina propria were increased in the acute phase of $\mathrm{KD}$ (arrows).

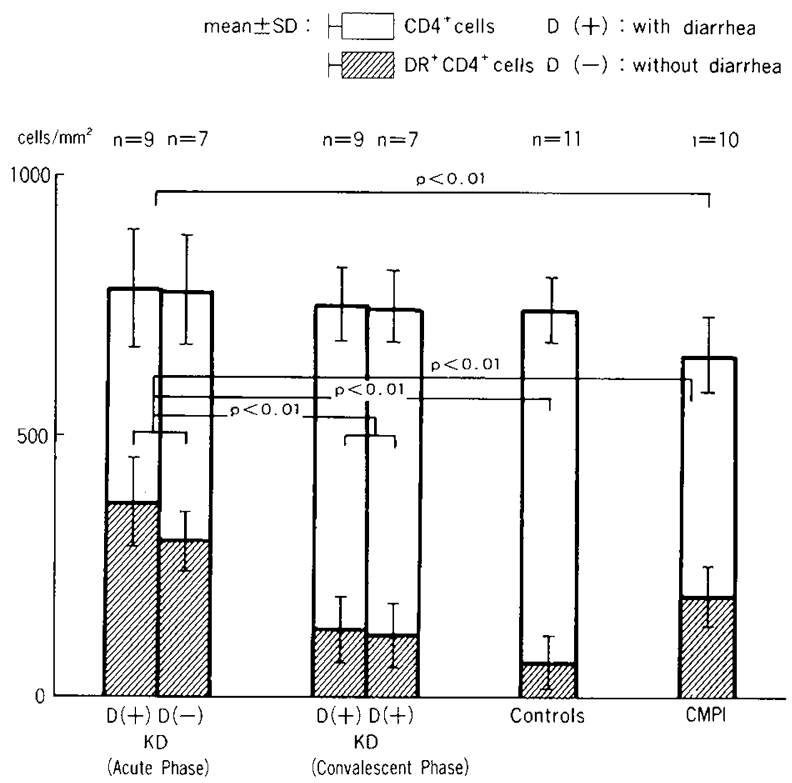

Fig. 5. Numbers of $\mathrm{CD}^{+}$and $\mathrm{DR}^{+} \mathrm{CD} 4^{+}$cells per $\mathrm{mm}^{2}$ of lamina propria. $\mathrm{DR}^{+} \mathrm{CD} 4^{+}$cells were significantly increased in the acute phase of $\mathrm{KD}$ in comparison with controls $(p \leq 0.01)$.

In all the $\mathrm{KD}$ and control specimens, most of the $\mathrm{CD}^{+}$cells were found in the lamina propria. The lamina propria $\mathrm{DR}^{+} \mathrm{CD}^{+}$ cells were significantly increased in the acute phase of $\mathrm{KD}$ in comparison with both control and CMPI tissue (Figs. 4 and 5). The total number of lamina propria $\mathrm{CD} 4^{+}$cells, was significantly reduced in CMPI patients (Fig. 5).

There were very few intraepithelial $\mathrm{CD}^{+}$cells, including $\mathrm{DR}^{+} \mathrm{CD} 4^{+}$cells. The number of $\mathrm{CD} 4^{+}$cells in tissue taken during the acute phase of KD did not differ statistically from that in control material. However, these cells were significantly increased in CMPI biopsies (Fig. 6).

Most of the $\mathrm{CD} 8^{+}$cells, in contrast to the $\mathrm{CD} 4^{+}$cells, were found in the epithelium in both KD and control specimens. Both intraepithelial and lamina propria $\mathrm{CD} 8^{+}$cells were significantly reduced in the acute phase of $\mathrm{KD}$ in comparison with both controls and CMPI patients (Figs. 7-9). No DR ${ }^{+} \mathrm{CD}^{+}$cells were observed in the IEL; all the $\mathrm{DR}^{+}$cells in the IEL were $\mathrm{CD}^{+}$ 


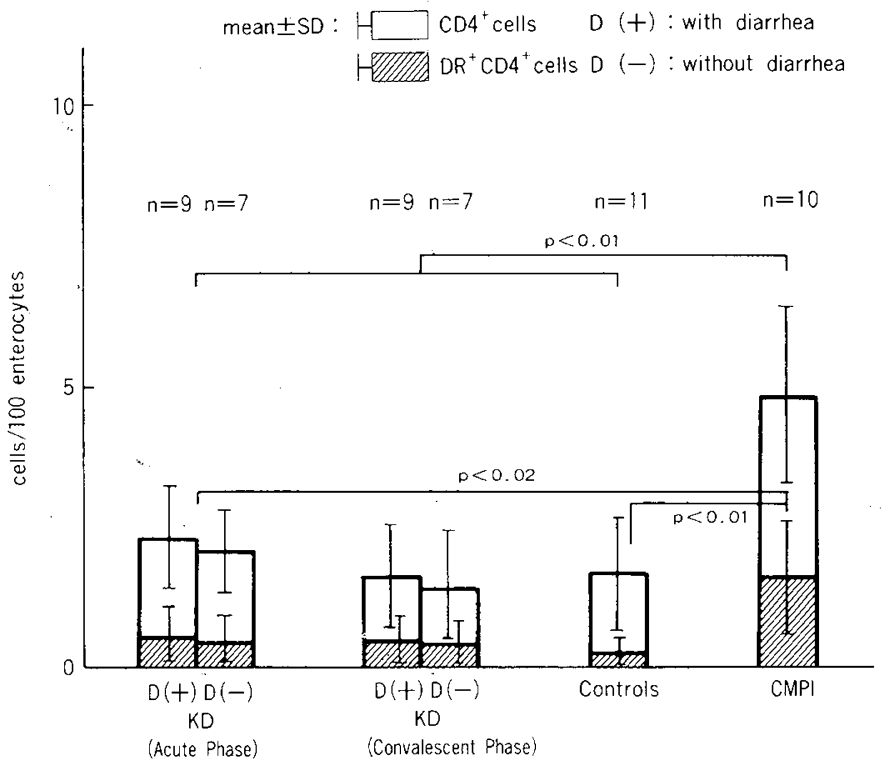

Fig. 6. Numbers of intraepithelial $\mathrm{CD}^{+}$and $\mathrm{DR}^{+} \mathrm{CD} 4^{+}$cells per 100 enterocytes. There were very few of these cells in the acute phase of $\mathrm{KD}$ or in the controls. The difference in the number of $\mathrm{CD}^{+}$cells was not significant. However, these cells were significantly increased in CMPI specimens.

cells. HLA-DR ${ }^{+}$lamina propria cells, which may include B cells, macrophages, activated $T$ cells, etc., were significantly increased in the acute phase of $\mathrm{KD}$ compared with controls (Fig. 10 and 11).

The number of $\mathrm{DR}^{+}$enterocytes was also significantly increased in the acute phase of $\mathrm{KD}$ compared with that in the controls (Figs. 10 and 12). The normal villous epithelium showed striking apical expression of HLA-DR. In the lamina propria, some round cells expressed HLA-DR (Fig. 10B).
Compared with normal controls, $\mathrm{HLA}_{-} \mathrm{DR}^{+}$enterocytes were increased in the acute phase of KD. This occurred not only in the upper villous areas but also extended toward the bottom of the villi (Fig. 10A). Similarly, $\mathrm{DR}^{+}$cells in both the lamina propria and enterocytes were significantly increased in CMPI specimens.

The pattern of increased $\mathrm{DR}^{+} \mathrm{CD}^{+}$and $\mathrm{HLA}-\mathrm{DR}^{+}$cells and reduced $\mathrm{CD} 8^{+}$cells in the acute phase of $\mathrm{KD}$ tended to normalize in the convalescent phase. This pattern was observed in patients with and without diarrhea. However, this immunohistochemical pattern tended to be more marked in patients with diarrhea than in those who did not have diarrhea (Figs. 2, 3, 5, 6, 8, 9, 11, and 12).

In the KD patient with severe, watery diarrhea accompanied by protein-losing enteropathy (Table $1, \mathrm{KD}$ : case 2 ), the immunohistochemical features in the mucosa of increased $\mathrm{DR}^{+} \mathrm{CD} 4^{+}$ and HLA-DR ${ }^{+}$cells and reduced $\mathrm{CD} 8^{+}$cells were more prominent than in the other subjects.

\section{DISCUSSION}

Mononuclear cell subsets in the peripheral blood, skin lesions, and coronary endothelial cells have been investigated in KD patients in previous studies. Leung et al. (4) demonstrated that, during the acute phase of $\mathrm{KD}$, there was a significant reduction in circulating $\mathrm{CD} 8^{+}$suppressor/cytotoxic $T$ cells and an increased number of activated $\left(\mathrm{DR}^{+}\right)$circulating $\mathrm{CD}^{+}$helper/inducer $\mathrm{T}$ cells.

Terai et al. (4) reported that patients who developed coronary aneurysms had an imbalance between $\mathrm{CD} 4^{+}$and $\mathrm{CD} 8^{+}$cells in the coronary endothelium, characterized by a reduction in the number of $\mathrm{CD} 8^{+}$cells and an increase in $\mathrm{CD} 4^{+}$cells. In addition, these investigators found that the majority of endothelial cells in the coronary arteries, veins, and capillaries expressed HLA-DR antigen at the inflammatory sites where macrophages and T cells coexisted.
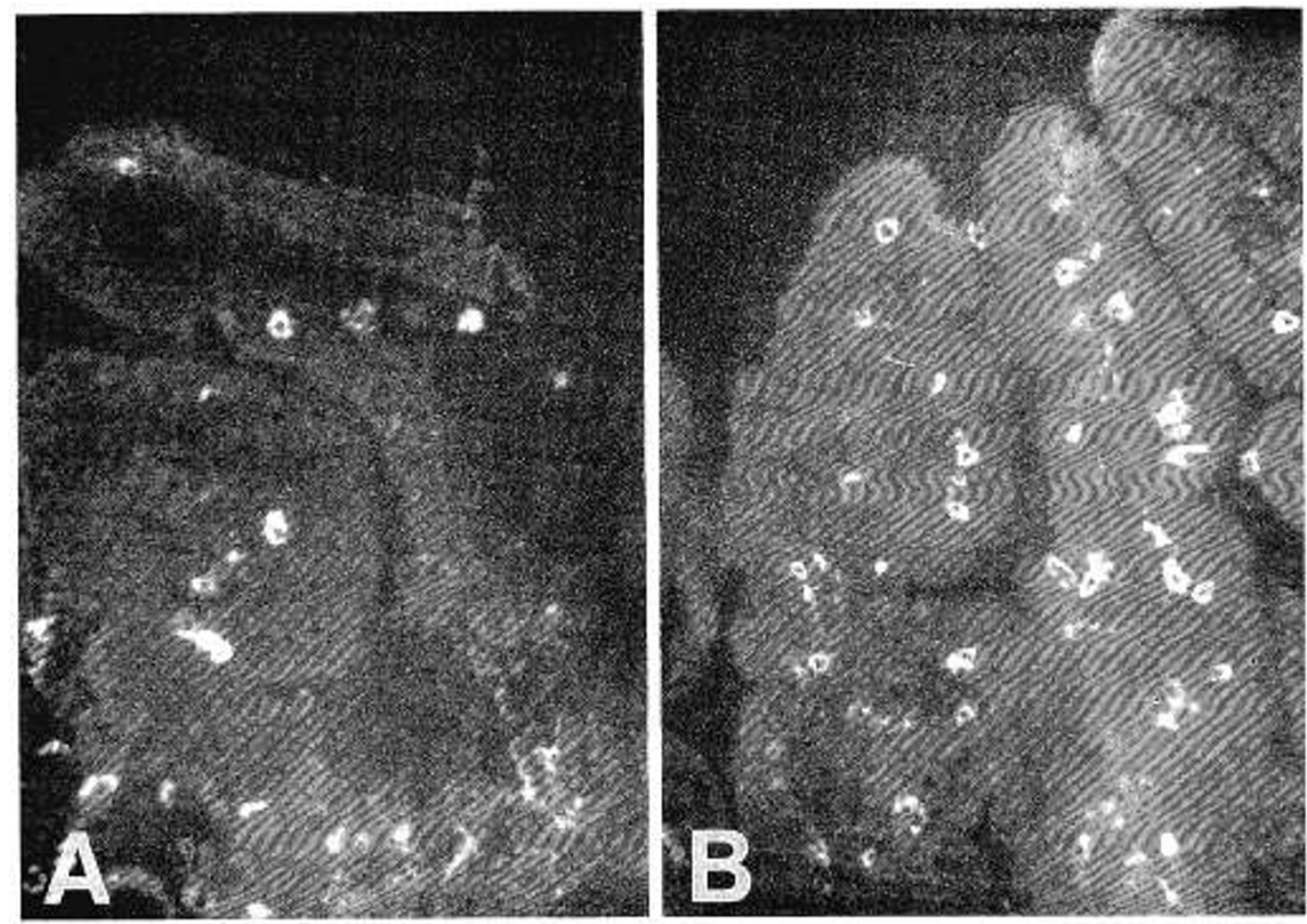

Fig. 7. $A, \mathrm{CD} 8^{+}$cells in the mucosa of the small intestine of $\mathrm{KD}$ in the acute phase. $B$, These cells in a control $(\times 200)$. Most of the $\mathrm{CD} 8^{+}$cells were found in the epithelium in both $\mathrm{KD}$ and control specimens. $\mathrm{CD} 8^{+}$cells were reduced in both the lamina propria and among the IEL in the acute phase of $\mathrm{KD}$. 


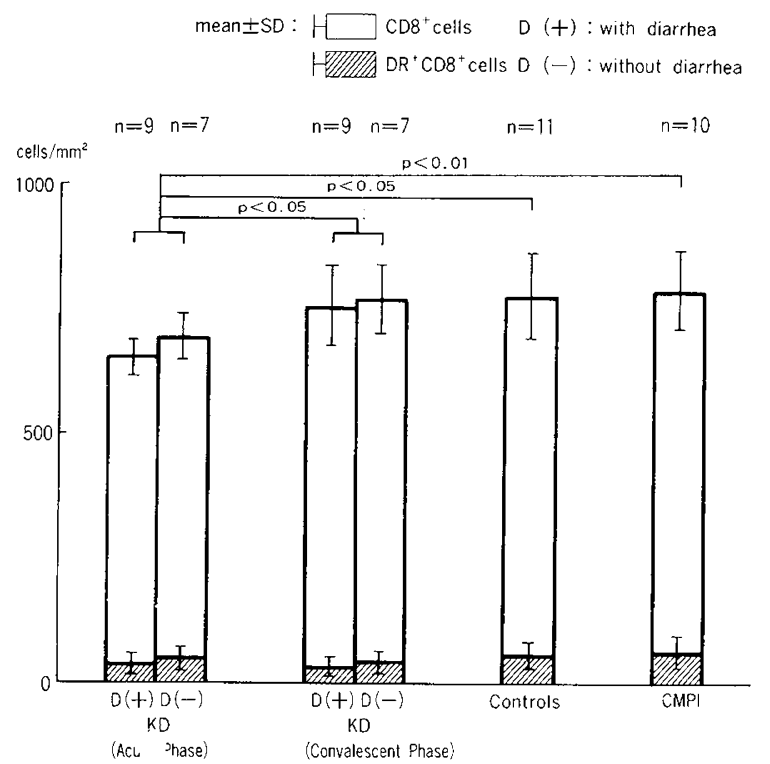

Fig. 8. Numbers of $\mathrm{CD}^{+}$and $\mathrm{DR}^{+} \mathrm{CD} 8^{+}$cells per $\mathrm{mm}^{2}$ of lamina propria. $\mathrm{CD} 8^{+}$lamina propria cells were significantly reduced in the acute phase $(p \leq 0.05)$.

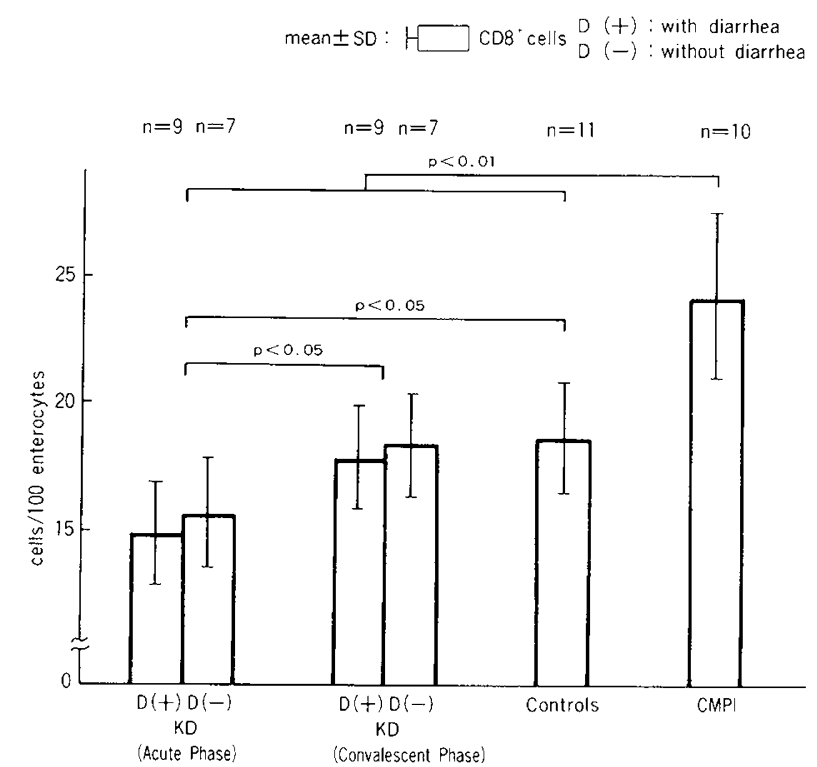

Fig. 9. Numbers of intraepithelial $\mathrm{CD} 8^{+}$cells per 100 enterocytes. Intraepithelial $\mathrm{CD} 8^{+}$cells were significantly reduced in the acute phase of $\mathrm{KD}(p \leq 0.05)$. No $\mathrm{DR}^{+} \mathrm{CD} 8^{+}$cells were observed in the IEL.

Sugawara et al. (6) reported that most of the mononuclear cells in the skin lesions of $\mathrm{KD}$ they examined were activated $\left(\mathrm{DR}^{+}\right) \mathrm{CD}^{+}$cells, and that $\mathrm{CD} 8^{+}$cells were reduced and were negative for HLA-DR antigen.

It is now well known that the GI tract serves a crucial immunologic function and that it is, in fact, the largest lymphoid tissue in the body. It is conceivable that the GI tract's role as an immunologic organ relates to its anatomical features and to the fact that it is always exposed to a milieu of microorganisms, various antigens, and other agents.

We focused on the fact that diarrhea is quite often one of the initial symptoms in the acute phase of KD. We hypothesized that the mucosa of the small intestine could be one of the primary sites of entry of the causative antigen and that systemic immunologic reactions might well follow this event. Pursuing this hypothesis, we investigated the mucosa of the small intestine via immunopathologic techniques. Our present study demonstrated that the pattern of cell surface phenotypes, i.e. the reduced $C D 8^{+}$ cells, and increases in activated $\mathrm{CD}^{+}$and $\mathrm{HLA}-\mathrm{DR}^{+}$cells in the mucosa were similar to the alterations observed in lymphocyte populations when T-cell-mediated delayed-type hypersensitivity occurs in this mucosa (7-9). It is certainly true that there is some variability of HLA-DR expression in the normal intestine and it is difficult to interpret changes in immunopathologic patterns with complete confidence. However, the pattern observed in the acute $\mathrm{KD}$ (decreased $\mathrm{CD} 8^{+}$cells, increased HLA-DR ${ }^{+}$cells and activated $\mathrm{CD} 4^{+}$cells) is consistent with what one would expect to see in a delayed-type hypersensitivity reaction.

Most HLA-DR ${ }^{+}$cells are thought to be antigen-presenting cells. Our results show an increased number of $\mathrm{HLA}-\mathrm{DR}^{+}$cells in enterocytes and mononuclear cells in the lamina propria; it is certainly conceivable that these cells are activated by antigen stimulation (10). It is of course possible that enhanced expression of HLA-DR on enterocytes largely reflects inflammatory changes. However, it is also quite conceivable that the enhanced expression of HLA-DR results from a presentation of antigens to the enterocytes. The reports of Sugawara et al. $(6,11)$ may be taken as further support for this supposition, inasmuch as they found that Langerhans cells, antigen-presenting cells in the skin, did not show enhanced expression of HLA-DR in KD.

However, because the pattern of cell-surface phenotypes in the mucosa of the small intestine was similar to that reported in peripheral blood mononuclear cells, skin lesions, and coronary arteries, we cannot deny the possibility that the findings in the mucosa of the small intestine were part of the systemic reaction in $\mathrm{KD}$.

The immunohistochemical disparity between acute KD and CMPI seems to offer an explanation for the immunologic specificity of the mucosa of the small intestine in KD irrespective of the presence of diarrhea. The immunohistochemical patterns noted above tended to be more marked in patients with diarrhea than in those without diarrhea. We found that the above-mentioned immunohistochemical pattern in the mucosa of the small intestine was most prominent in the KD patient who had severe, watery diarrhea accompanied by protein-losing enteropathy. This is consistent with the immunologic specificity of the intestinal mucosa in KD. These findings would appear to indicate that diarrhea in KD may be provoked secondarily by immunologic mechanisms. On the other hand, although it is thought that enterocytes that express HLA-DR in CMPI are antigen-presenting cells, we found that the immunopathologic pattern in the mucosa of the small intestine in that disease differed from that in KD. Those differences could be due to antigen specificity. Alternatively, the differences in the immunopathologic patterns of the mucosa in the two diseases may reflect varying time courses and mechanisms of action. Mucosal changes in CMPI may be mediated by chronic immunologic mechanisms and modified by secondary feedback phenomena. In contrast, the patterns in $\mathrm{KD}$ may be mediated by acute immunologic mechanisms.

Figure 13 diagrams a possible immunopathologic mechanism in the mucosa of the small intestine in KD. Briefly, antigen may overstimulate antigen-presenting cells and $\mathrm{CD}^{+}$cells and thus give rise to an increased proportion of activated $\mathrm{CD}^{+}{ }^{+}$cells and enhanced expression of epithelial HLA class II (predominantly HLA-DR). Enhanced expression of epithelial HLA-DR may induce the activation of $\mathrm{CD}^{+}$cells and the down-regulation of $\mathrm{CD} 8^{+}$cells. Then, the causative antigen that has invaded through the small intestinal mucosa may induce a systemic immunologic reaction.

Leung et al. $(12,13)$ suggested that the antigen may possibly alter the lymphocyte population, e.g. by reducing $\mathrm{CD} 8^{+}$cells and/or increasing $\mathrm{DR}^{+} \mathrm{CD} 4^{+}$cells or by bringing about marked polyclonal $B$ cell activation. These investigations suggested that vasculitis in $\mathrm{KD}$ might be due to cytotoxic antibodies directed against the target antigen that had been induced on the vascular 

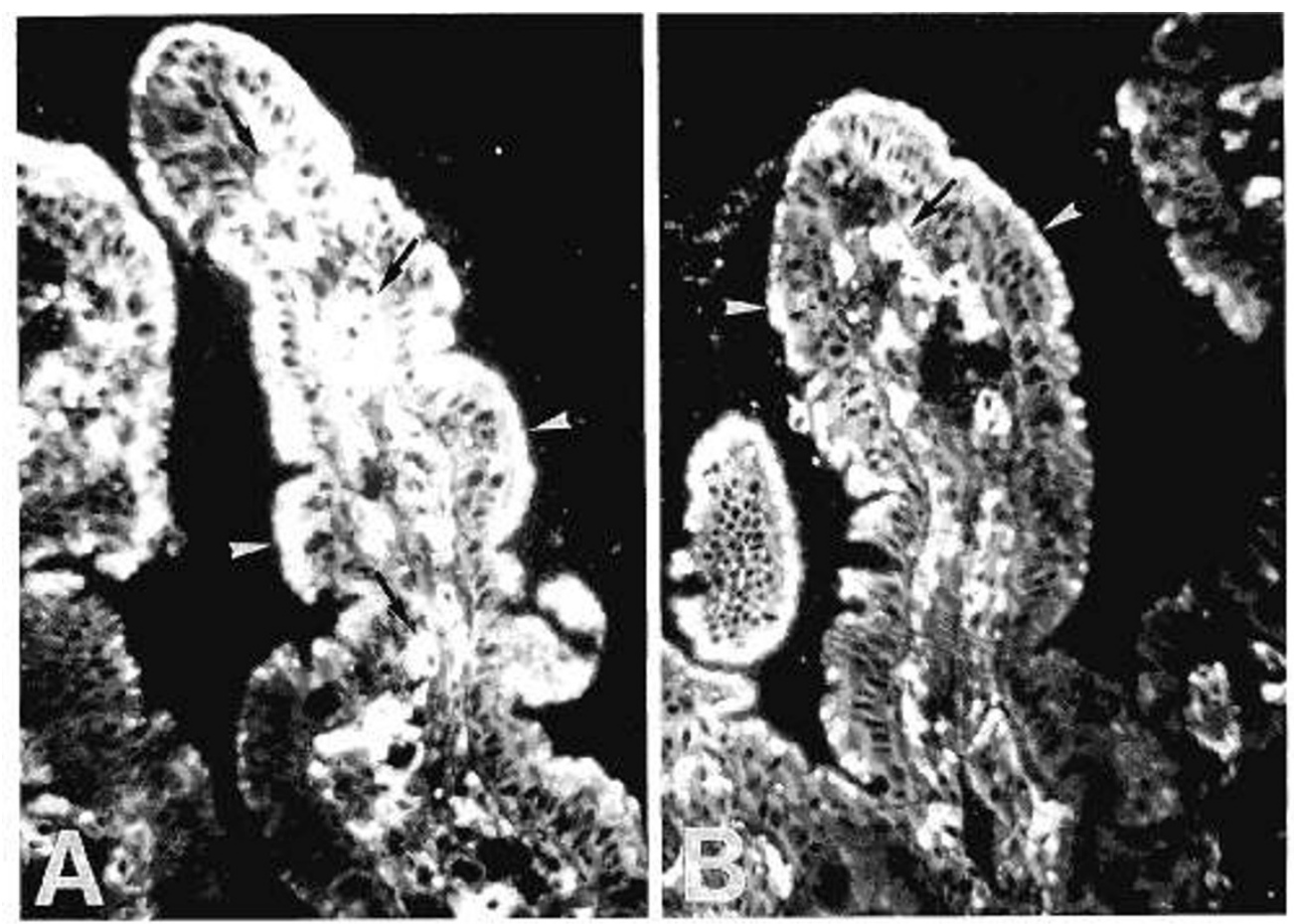

Fig. 10. $A, \mathrm{HLA}-\mathrm{DR}^{+}$cells in the mucosa of the small intestine during the acute phase of $\mathrm{KD} . B$, Biopsy from a control $(\times 200)$. HLA-DR ${ }^{+}$cells were increased in both the epithelium (arrow heads) and the lamina propria (arrows) in the acute phase of KD.

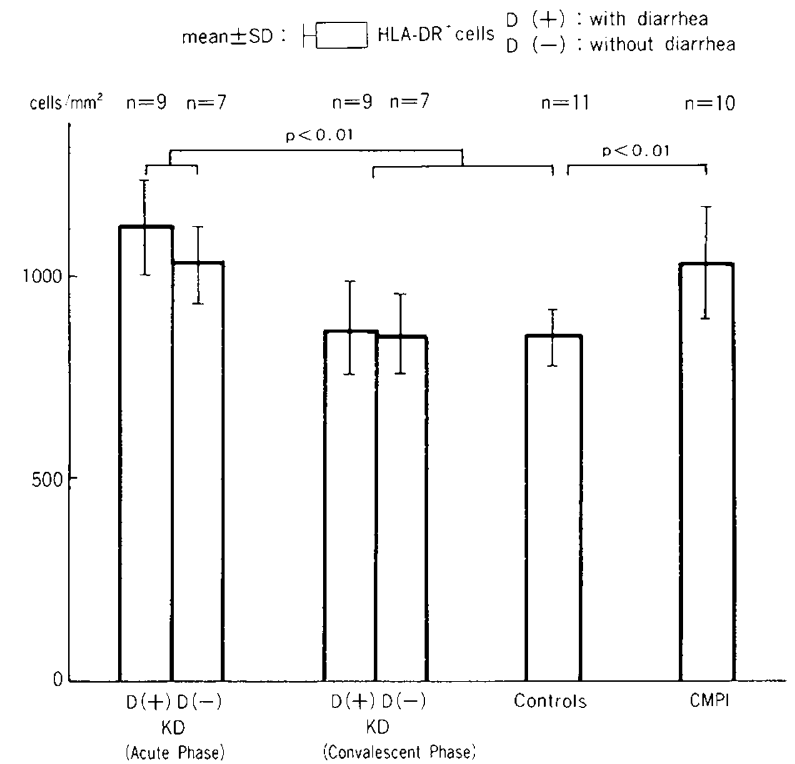

Fig. 11. Total numbers of $\mathrm{DR}^{+}$cells per $\mathrm{mm}^{2}$ of lamina propria. $\mathrm{DR}^{+}$ lamina propria cells were significantly increased in the acute phase of $\mathrm{KD}(p \leq 0.01)$.

endothelium by cytokines released from activated $\mathrm{CD}^{+}$and other cells.

Regarding the causative antigen, certain microorganisms, such as retroviruses, Epstein-Barr virus, Streptococcus pyogenes, Streptococcus sanguis, and Propionibacterium acnes, have been suggested. However, to date, no causative antigen has been confirmed (14-18). Although we have hypothesized that KD may be a systemic reaction to an antigen originally introduced through the GI tract, we have been unable to identify a causative agent as yet. We continue our search for this agent.

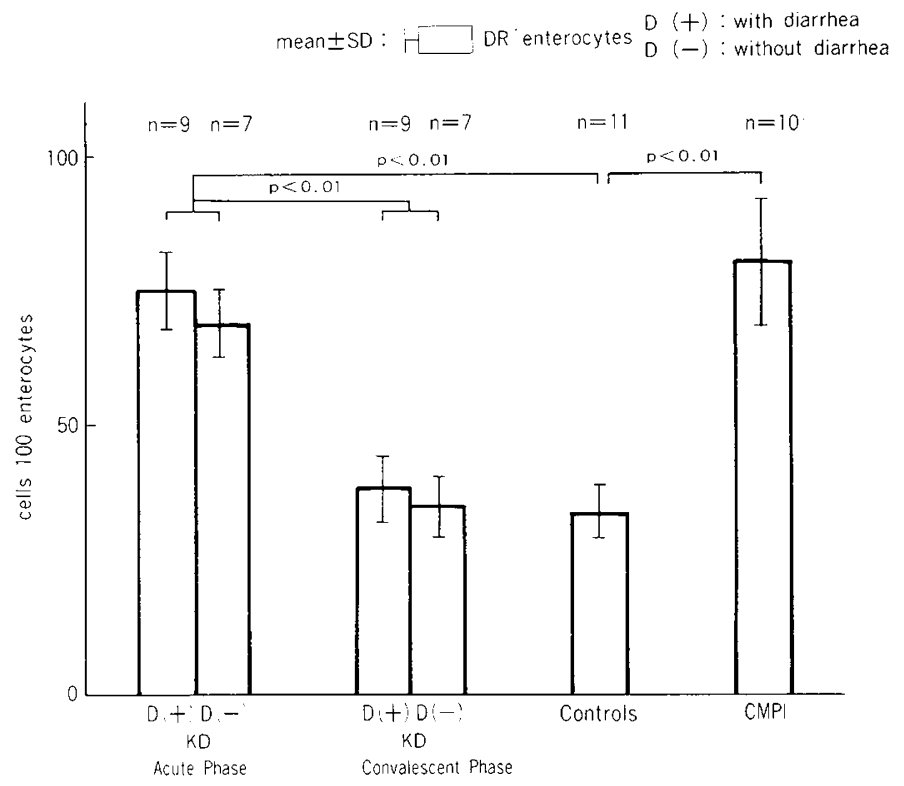

Fig. 12. Numbers of $\mathrm{DR}^{+}$enterocytes per 100 entrocytes. $\mathrm{DR}^{+}$enterocytes were significantly increased in both the acute phase of KD and in CMPI $(p \leq 0.01)$.

Acknowledgments. The authors thank Prof. J. Walker-Smith, Dr. A. D. Phillips (The Academic Department of Child Health, Queen Elizabeth Hospital for Children, London), Dr. T. T. MacDonald (Department of Paediatric Gastroenterology, St. Bartholomews Hospital, London), and Prof. T. Shirai (Department of Pathology, Juntendo University School of Medicine, Tokyo) for reviewing this manuscript before publication and offering many valuable suggestions. 


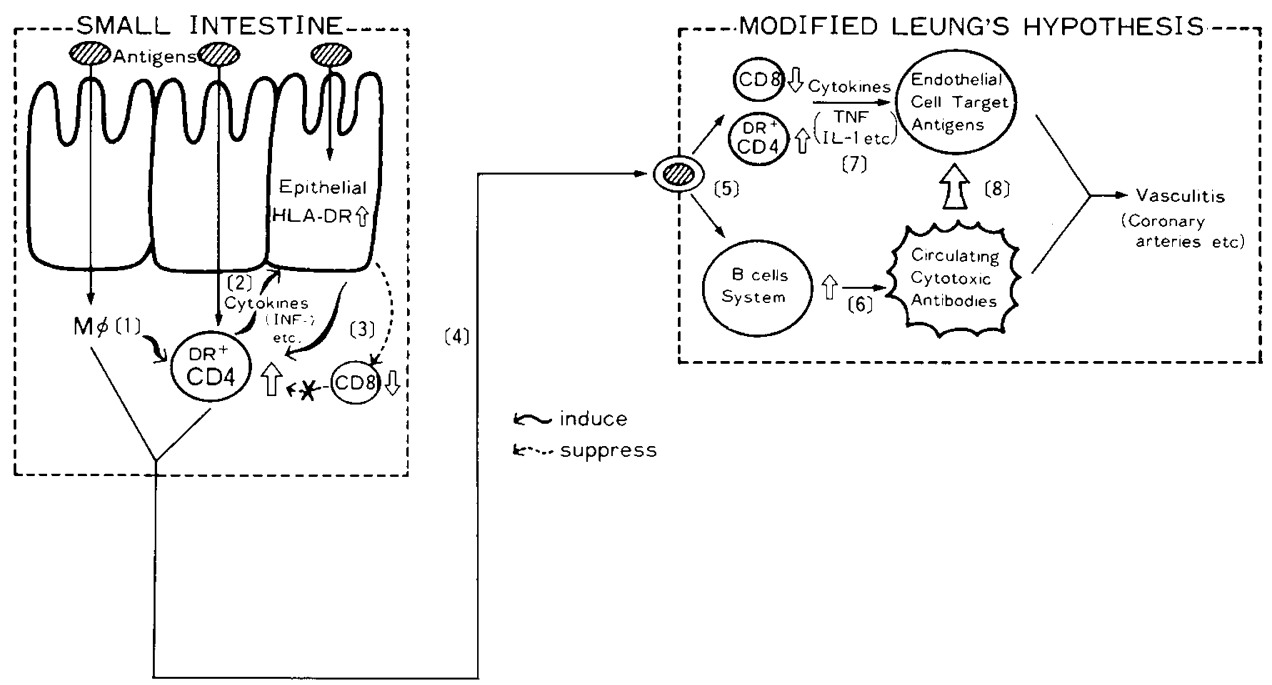

Fig. 13. Putative immunopathologic mechanism in KD. $I N F-\gamma$, interferon- $\gamma ; T N F$, tumor necrosis factor. 1 , An antigen overstimulates antigenpresenting and $\mathrm{CD}^{+}$cells. 2, Cytokines from stimulated $\mathrm{CD}^{+}$cells induce epithelial HLA-DR. 3, $\mathrm{DR}^{+}$epithelial cells mediate enhanced presentation of antigens and induce the activation of $\mathrm{CD}^{+}$cells and the down-regulation of $\mathrm{CD} 8^{+}$cells. 4 , The antigen that has invaded the mucosa induces systemic immunologic reactions. 5, The antigen alters the lymphocyte population. 6 , Abnormal B cells produce cytotoxic antibodies. 7, Cytokines from $\mathrm{CD}_{4}{ }^{+}$cells and/or macrophages etc. induce endothelial cell target antigens. 8 , The antibodies attack the target antigens, resulting in vasculitis.

\section{REFERENCES}

1. Kawasaki T 1967 Acute febrile mucocutaneous syndrome with lymphoid involvement with specific desquamation of the fingers and toes in children: clinical observations of 50 cases. Jpn J Allergol 16:178-222

2. Kawasaki T, Kosaki F, Osawa S, Shigematsu I, Yanagawa H 1984 A new infantile acute febrile mucocutaneous lymph node syndrome (MCLS) prevailing in Japan. Pediatrics 54:271-276.

3. Leung DYM, Siegel RL, Grady SR 1982 Immunoregulatory abnormalities in MCLNS. Clin Immunol Immunopathol 23:100-112

4. Leung DYM, Chu ET, Wood N 1983 Immunoregulatory $T$ cell abnormalities in MCLNS. J Immunol 130:2002-2004

5. Terai $T$, Kohno Y, Niwa K 1987 Imbalance among $T$ cell subsets in patients with coronary arterial aneurysms in Kawasaki disease. Am J Cardiol 60:555559

6. Sugawara T, Furukawa S, Yabuta K, Shirai T 1987 Immunopathology of the skin lesions of Kawasaki disease. In: Shulman ST (ed) Kawasaki Disease. Alan R Liss, New York, pp 185-192

7. Dvorak AM, Mihm Jr MC, Dvorak HF 1976 Morphology of delayed-type hypersensitivity reactions in man. Lab Invest 34:179-191

8. Bennett B, Bloom BR 1968 Reactions in vivo produced by a soluble substance associated with delayed-type hypersensitivity. Proc Natl Acad Sci USA 59:756-762

9. Waksman B 1971 Delayed (Cellular) Hypersensitivity in Immunological Disease. Little Brown, Boston, pp 220-252

10. Brandtzaeg P, Halstensen TS, Kett K, Krajci P, Kvale D, Rognum TO, Scott $\mathrm{H}$, Sollid LM 1989 Immunobiology and immunopathology of human gut mucosa. Gastroenterology 97:1562-1584
11. Sugawara T 1991 Immunopathology of skin lesions in Kawasaki disease. Jpn J Allergol 40:476-482

12. Leung DYM, Collins T, Lapierre LA, Geha RS, Pober JS 1986 Immunoglobulin $\mathrm{M}$ antibodies present in the acute phase of Kawasaki Syndrome lyse cultured vascular endothelial cells stimulated by gamma interferon. J Clin Invest 77:1428-1435

13. Leung DYM, Geha RS, Newburger JW, Burns JC, Fiers W, Lapierre LA, Pober JS 1986 Two monokines, interleukin I and tumor necrosis factor, render cultured vascular endothelial cells susceptible to lysis by antibodies circulating during Kawasaki disease. J Exp Med 164:1958-1972

14. Burns JC, Geha RS, Schneeberger EE, Newburger FS, Glezen LS, Huang AS, Natale J, Leung DYM 1986 Polymerase activity in lymphocyte culture supernatants from patients with Kawasaki disease. Nature 323:814-816

15. Okamoto T, Kuwabara H, Shimotohno K, Sugimura T, Yanase Y, Kawasaki T 1988 Lack of evidence of retroviral involvement in Kawasaki disease. Pediatrics 81:599

16. Kikuta H, Taguchi Y, Tomizawa K, Kojima K, Kawamura N, Ishizuka A, Sakiyama $Y$, Matsumoto S, Imai S, Kinoshita T, Koizumi S, Osato T, Kobayashi Y, Hamada 1, Hirai K 1988 Epstein-Barr virus genome-positive $\mathrm{T}$ lymphocytes in a boy with chronic active $\mathrm{EBV}$ infection associated with Kawasaki-like disease. Nature 333:455-457

17. Okano M, Sakiyama Y, Matsumoto S 1986 Antibody studies on Epstein-Barr virus (EBV) in patients with EBV-associated disease. Clin Pediatr Med 34:9397

18. Kawai M, Osawa N, Yamaura N 1989 Possible role of streptococcus pyogenes in mucocutaneous lymph node syndrome IX: quantitation by ELISA of streptococcal pyogenic exoptoxin in the serum of MCLS patients. Acta Paediatr Jpn 31:529-536 